Araștırma Makalesi

\title{
Red Meat Consumption Structure and Consumer Behavior in the Urban Area of Adana Province
}

\author{
N'djambieri Yacouba SORO ${ }^{1 *}, \quad$ Ufuk GÜLTEKIN ${ }^{1}$
}

\begin{abstract}
In this study, to determine the red meat consumption structure and consumer behavior in different income groups, 400 persons have been subjected to a questionnaire. Red meat consumption habits and consumers' family preferences were also determined. According to research findings, the per capita annual intake of red meat was $22,02 \mathrm{~kg}$. It was found that the most favored form of meat was boneless meat regardless of the income level, given the red meat intake of the individuals subjected to this study. In the study, $57.9 \%$ of customers prefer conventional butcher shops to purchase red meat when the butcher is known to be familiar. Consumers like red meat because it is inexpensive, nutritious and easy to access. In addition, 30\% of customers who partook in the survey were willing to pay more for red meat in food safety. $74.6 \%$ of the people who took part in the study were determined to consume more red meat if the price lowered by $30 \%$. In order to analyze the factors that influence the red meat buying place of the families participating in this research the binary logit model was used. As per the results of the logit model it has been established that the family's red meat buying place was influenced by variables like income, education, quantity, proximity, fresh meat, affordable price.
\end{abstract}

Keywords: Red meat, Binary logit model, Consumer behavior, Consumption structure

\section{Adana İli Kentsel Alanda Kırmızı Et Tüketim Yapısı ve Tüketici Davranışları}

\begin{abstract}
ÖZ
Bu çalışmada, farklı gelir gruplarında kırmızı et tüketim yapısını ve tüketici davranışını belirlemek amacıyla 400 kişiye anket uygulanmış ve kırmızı et tüketim alışkanlıkları ile tercihleri belirlenmiştir. Araştırmadan elde edilen bulgulara göre kişi başına yıllık kırmızı et tüketimi 22,02 kg'dır. Kişilerin kırmızı et tüketimi göz önüne alındığında, gelir grubu ne olursa olsun en çok tercih edilen et çeşidinin kemiksiz et olduğu belirlenmiştir. Buna ek olarak, kırmızı eti sırasıyla ucuz, sağlıklı ve kolay ulaşılabilir olması nedeniyle satın alma yeri olarak tüketicilerin \%57.9 geleneksel kasap dükkanlarını tercih ettikleri belirlenmiştir. Ayrıca çalışmaya katılan tüketicilerin \%30'u gıda güvenliği açısından kırmızı ete fazladan ödeme yapma istekliliğindedirler. Araştırmaya katılanların \%74,6'sının kırmızı et fiyatının \%30 ucuzlaması durumunda daha fazla kırmızı et tüketme istekliliği tespit edilmiştir. Bu araştırmaya katılan ailelerin kırmızı et satın alma yerini etkileyen faktörleri analiz etmek için ikili logit modeli kullanılmıştır. Logit modeli sonuçlarına göre, ailelerin kırmızı et tüketim yerlerinin; gelir, eğitim, miktar, yakınlık, taze et, uygun fiyat değişkenlerden etkilendiği belirlenmiştir. Anahtar Kelimeler: Kırmızı et, İkili logit modeli, Tüketici davranışı, Tüketim yapısı
\end{abstract}

ORCID ID (Yazar sirasına göre)

0000-0002-4194-9955, 0000-0002-4378-8868

\section{Introduction}

In order to sustain a safe and adequate diet, we need to eat food of animal origin. Animal products, like beef, milk and eggs are important for human nutrition. Among the most basic concerns for a healthy and nutritious diet, animal proteins consumed on a regularly should be approximately 40-50\% (Anonymous, 2015; Gogus, 1986).

\footnotetext{
Yayın Kuruluna Geliş Tarihi: 18.12.2020

Kabul Tarihi: 29.12.2020

${ }^{1}$ Çukurova Üniversitesi, Ziraat Fakültesi, Tarım Ekonomisi Bölümü, Sarıçam, Adana, Türkiye

*E-posta: ndjambierisoro2020@gmail.com
} 


\section{Red Meat Consumption Structure and Consumer Behavior in the Urban Area of Adana Province}

It is even possible to say that nowadays, the level of animal product consumption is an indicator of the country's development. Meat consumption is highest across high-income countries. The most significant factor deciding the purchase is the income of individuals. Income disparity is the first of the most significant challenges affecting developed and developing countries. This disparity in income distribution also reflects the trend of individual consumption. While the per capita intake of meat in Australia is approximately $116 \mathrm{~kg}$, it is about $80 \mathrm{~kg}$ and more than $110 \mathrm{~kg}$ respectively in Europe and North America. (Anonymous, 2016) and in Turkey, it is $14.70 \mathrm{~kg}$ (TÜİK, 2018).

A number of studies has been conducted on the consumption of red meat (Hanta, 1984; Akdemir, 1989; Gökçek, 1998; Upton, 2004; Akbay, 2005; Ceylan, 2006; Sanchez et al., 2001; Hatırlı et al., 2007; Mutlu, 2007; Yen et al., 2008; Cankurt et al., 2010; Yaylak et al., 2010; Kızıloğlu and Kızıloğlu, 2013; Lorcu and Bolat, 2012). This study will contribute to the growing literature on red meat consumption, consumers' behavior and also underlines the value of red meat. The findings of this research were compared to literature studies.

In addition to efforts to increase the production of meat for nutritious and proper human consumption, other factors influencing consumer meat intake are also significant. The research conducted in the central region of Adana, examined the factors that influence the consumption of red meat by determining the domestic trend in the consumption of red meat. The choices for consumer consumption of red meat and factors influencing consumer preferences and the value of red meat in the family diet profile has therefore been defined.

\section{Materials and Methods}

Data from the survey conducted with families in the central district of Adana in 2019 were the main material of the report. As in several studies, the following approach was used to achieve a full scale (Armağan and Akbay, 2007; Pazarlioglu and al. 2007; Uzunoz and al. 2011).

$n=\frac{N p(1-p)}{(N-1) \sigma_{p}^{2}+p(1-p)}$ $\mathrm{n}=$ Sample size,

$\mathrm{N}=$ population size,

$\mathrm{p}=$ probability of the situation being searched (it is assumed 0.50 to reach maximum sample size), $\sigma_{p}^{2}=$ Probability variance.

The properties of the main mass of consumers forming are not known; therefore, the p-value will be 0.5 to maximize the size. As a result of the calculation, the sample volume was found as 400.

The number of surveys carried out was divided into three groups in the determination of income groups. The income levels of households are divided as 0-2500 TL (low-income group, 118), 2501 - 4000 TL (average-income group, 167) and 4001 TL and above (high-income group, $115)$.

The chi-square test was used in the study to reveal that some of the results obtained as a percentage were statistically significant.

The Logit model was used in the analysis to assess the factors influencing the purchasing of red meat by consumers in the central district of Adana. The socio-economic aspects of the customer profile, such as consumer attitudes and behaviors, have also been discussed in the Logit regression analysis process. The Logit regression model is a nonlinear regression model designed for at least two dependent variables. In other words, it is a non-linear model that can be linearized with the necessary conversions (Stock and Watson, 2007). The Logit model defining the logistic distribution function can be given as follows (Grene, 2000).

$\mathrm{P}_{i}=\frac{1}{1+\mathrm{e}^{-(\beta 0+\beta 1 \mathrm{Xi})}}$

The binary logit regression model, which is one of the limited dependent variable models, was used to determine the probability of consumers who prefer to buy red meat on the market or not and also to determine the factors affecting these possibilities.

\section{Results and Discussion}

The consumers surveyed consisted of $60 \%$ male and $40 \%$ female. As for the educational status of those studied, they are $0.2 \%$ illiterate, $22 \%$ elementary school graduates, $10.2 \%$ middle school graduates, $40 \%$ high school graduates, and $27.5 \%$ university graduates. 


\section{Red Meat Consumption Structure and Consumer Behavior in the Urban Area of Adana Province}

Of the persons surveyed, they are workers by $31 \%$, officer by $20 \%$, housewife by $19 \%$, and $3.2 \%$ are unemployed. Of the customers surveyed, the total number of family members is 3.07.

In the research conducted, the average income of the households was determined as $3887.75 \mathrm{TL}$ per month. The average monthly income of households in the low-income group is 2172.03 TL, the average monthly income of the households in the average-income group is 3 $379.64 \mathrm{TL}$ and the average monthly income of the households in the higher- income group is up to 6386.09 TL. Monthly food expenditure of the consumers is $711.55 \mathrm{TL}$ on average in the lowerincome group, $912.50 \mathrm{TL}$ in the average income group, and 988.12 in the higher income group.

Red meat consumption per capita was $22.05 \mathrm{~kg}$ annually. In another study in 2017, Merve (2017) found that annual per capita intake of red meat in Tokat was $26.34 \mathrm{~kg}$ per capita. Also, in a survey conducted in urban areas of Erzurum in 2013, it was determined that the annual red meat consumption per household was $59.76 \mathrm{~kg}$ and the consumption per person was $14.16 \mathrm{~kg}$
(Kızıloğlu and Kızıloğlu, 2013). In research conducted in Isparta in 2007, red meat consumption per person was determined as 7.20 $\mathrm{kg}$ (Hatirli et al., 2007). In another study conducted in Urfa in the same year, the annual red meat consumption of the households was $70.32 \mathrm{~kg}$ (Karlı and Bilgiç, 2007). In a study conducted in Van in 2006, the total red meat consumption of households was determined as $71.23 \mathrm{~kg}$ (Ceylan, 2006). Also, in a study conduct in Adana in 2007 by Mutlu red meat consumption was $19.68 \mathrm{~kg}$ per year per capita. Another factor that is effective on the amount of red meat consumption, as well as the income level, is the education level. It has been determined that a consumer with an education level of Associate degree and above prefers red meat over the average (22.05). There was a significant relationship between the amount of red meat consumption and the level of education at a 5\% significance level. Based on these findings, it is concluded that the amount of red meat consumption increases as the education level of the consumer increases.

Table 1. Relationship between education level and consumption

\begin{tabular}{lllll}
\hline & $\begin{array}{l}\text { Primary school and } \\
\text { under }\end{array}$ & $\begin{array}{l}\text { Middle } \\
\text { school and } \\
\text { high school }\end{array}$ & $\begin{array}{l}\text { Associate degree and } \\
\text { above }\end{array}$ & $\begin{array}{l}\text { Total } \\
\text { average }\end{array}$ \\
\hline$\mu>$ & 35.6 & 20.2 & 27.9 & 25.5 \\
$\mu<$ & 64.4 & 79.8 & 72.1 & 74.5 \\
Total & 100.0 & 100.0 & 100.0 & 100.0 \\
\hline Khi-square & Khi square value $\left(\mathbf{X}^{\mathbf{2}}\right)$ & $\mathbf{P - v a l u e}$ & \\
analysis results & $\mathbf{7 . 2 5 1}$ & $\mathbf{0 . 0 2 7}$ & \\
\hline
\end{tabular}

According to this study, the high-income group people consume red meat at least once or three times a week. For the low- and average-income groups it is mostly once a month. Consumers' preferences of red meat type by income group were examined and no matter the income group they prefer boneless meat.

Per the report, while $76.2 \%$ of consumers decreased their consumption relative to previous years, $13.8 \%$ increased their consumption. The most important reason for those who stated that red meat consumption has decreased in recent years is price increases $(57.4 \%)$. This was followed by the lack of income with $29.4 \%$, health problems with $7.1 \%$, and the lack of hygiene and reliability with $6.1 \%$.

$75.6 \%$ of the persons surveyed stated that they would change their consumption of red meat if it becomes cheaper by $30 \%$. As a result of chisquare analysis, a $10 \%$ and $30 \%$ decrease in red meat prices affected consumption and showed differences according to income groups. Accordingly, it was found statistically that consumers in low-income groups could increase their consumption amounts against price 


\section{Red Meat Consumption Structure and Consumer Behavior in the Urban Area of Adana Province}

decreases and it was found significant at a $1 \%$ level.

There was a significant relationship between the red meat purchase place and the education level. The proportion of those who only shop from the butcher decreases as the level of education increases. While $63 \%$ of primary school and under consumers prefer the only butcher, this rate is $55.6 \%$ for high-school consumers. As the level of education increases, the ratio of those who prefer only the market increases. While only $7.4 \%$ of primary school consumers preferred the market, $37.1 \%$ of the consumers who had education at the university level stated that they shop at the market. There is no significant difference between the ratio of those who prefer both a butcher shop and market and education levels. It was determined that the ratio of those who prefer both butcher shop and grocery store, and the ratio of those who cut themselves and those who received aid was higher in consumers with low educational level $(14.1 \%)$. This rate is $3.1 \%$ for those with higher education.

Table 2. Relationships between educational level and red meat purchase place

\begin{tabular}{|c|c|c|c|c|}
\hline & $\begin{array}{l}\text { Primary } \\
\text { school and } \\
\text { under }\end{array}$ & $\begin{array}{l}\text { Middle school } \\
\text { and high } \\
\text { school }\end{array}$ & $\begin{array}{l}\text { Associate } \\
\text { degree and } \\
\text { above }\end{array}$ & $\begin{array}{l}\text { Total } \\
\text { average }\end{array}$ \\
\hline Butcher & 63.0 & 55.6 & 46.7 & 55.1 \\
\hline Markets & 7.4 & 23.2 & 37.1 & 22.5 \\
\hline $\begin{array}{l}\text { Both (butcher } \\
\text { and market) }\end{array}$ & 15.1 & 18.2 & 13.2 & 15.5 \\
\hline Others & 14.1 & 3.0 & 3.1 & 6.9 \\
\hline
\end{tabular}

According to this study, the high-income group people consume red meat at least once or three times a week. For the low- and average-income groups it is mostly once a month and barely between three and five times a month. Consumers' preferences of red meat type by income group were examined and no matter the income group they prefer boneless meat.

According to the study, while $76.2 \%$ of the consumers decrease their consumption compared to previous years, $13.8 \%$ increase theirs. The most important reason for those who stated that red meat consumption has decreased in recent years is price increases $(57.4 \%)$. This was followed by the lack of income with $29.4 \%$, health problems with $7.1 \%$, and the lack of hygiene and reliability with $6.1 \%$.

$75.6 \%$ of the persons surveyed stated that they would change their consumption of red meat if it becomes cheaper by $30 \%$. As a result of chisquare analysis, a $10 \%$ and $30 \%$ decrease in red meat prices affected consumption and showed differences according to income groups. Accordingly, it was found statistically that consumers in low-income groups could increase their consumption amounts against price decreases and it was found significant at a $1 \%$ level.

The opinions of consumers about purchasing place preferences were evaluated by a Likert scale.

In order to determine the place of purchase, the fact that the meat is fresh at the place has been determined as the most important factor that consumers take into consideration (96.6\%). It can be stated that there is no significant difference between income groups. At the same time, the average score was high in each group and 3.41 in the overall average. $72 \%$ of consumers care about red meat prices being more affordable at the sale place. There is no significant difference between income groups. In the preference of red meat purchase place, the rate of those who did not care that the owner of the place purchased was familiar is $42.1 \%$. In today's conditions, red meat is considered to have an important rate in butchery as well as in grocery stores. In the choice of red meat buying place, the consumer must recognize the owner of the place due to the widespread butcher culture in the past, this culture continues despite the development and settlement of the market phenomenon. Taking into account the working 


\section{Red Meat Consumption Structure and Consumer Behavior in the Urban Area of Adana Province}

area, red meat is often preferred when the butchers are known to be familiar that is why $57.9 \%$ said it was important. It is determined that there is no significant difference in purchasing place preference concerning income groups.

When the consumers buy red meat, they pay attention mostly to their family member's preferences $(91.8 \%)$, price $(87.3 \%)$, and the origin of the animal (34\%).

Out of the participants of the study, $11.18 \%$ was ready to pay more in case of guaranteeing red meat reliability especially in the high-income group (15.02\%).

Logit Regression Model: In this study, the binary logit regression model, which is one of the limited dependent variable models, was used to determine the probability of consumers who prefer to buy red meat on the supermarket or not and also to determine the factors affecting these possibilities.
Six variables were found to be statistically significant in a single variable model trial for a total of eight independent variables. These variables are; income, education, amount, proximity, fresh meat, affordable price. All statistically significant variables were tested with multiple models and only four variables (education, amount of meat, being close, being fresh) were found to be statistically significant because of the final model variables on each other. Finally, the logit model;

Preference place $=\beta 0+\beta 1$ education $+\beta 2$ meat amount $+\beta 3$ Being close $+\beta 4$ Fresh formed and given in table 3 .

The likelihood ratio (Loglikelihood: 300.477) and the Goodness of fit of multiple models were found to be enough with $\mathrm{R}^{2}$ value (Cox \&Snell $R^{2}$ : 0.072; Nagelkerke $R^{2}$ : 0.122).

Table 3. Defining variables

\begin{tabular}{|c|c|}
\hline Variables & Definition \\
\hline The dependent variable & \\
\hline Place of purchase (preferred place) & $0=$ not market, $1=$ market \\
\hline Independent variables & \\
\hline Revenue (revenue) & Average monthly income of the consumer \\
\hline Education & $\begin{array}{l}1=\text { primary school and below } 2=\text { middle school and high } \\
\text { school } 3=\text { Associate degree and university }\end{array}$ \\
\hline Amount of red meat (quantity) & Amount of red meat per capita kg/year \\
\hline Being close & $\begin{array}{l}1=\text { not important } 2=\text { neither important nor not } 3= \\
\text { important }\end{array}$ \\
\hline Fresher at the place of purchase & $\begin{array}{l}1=\text { not important } 2=\text { neither important nor not } \\
\text { important }\end{array}$ \\
\hline Because prices are more affordable & $\begin{array}{l}1=\text { not important } 2=\text { neither important nor not } \\
\text { important }\end{array}$ \\
\hline
\end{tabular}

When buying red meat, it was a question of revealing the possibility for consumers to prefer the market or not. In the dependent variable, those outside the market (0) are determined as the reference category. This indicates that consumers may prefer to buy red meat outside the market. The results of the binary logit model are given in Table 4.

Education can be seen as an important factor for consumers to choose whether to buy red meat in a market or not. The relationship between the level of education and the possibility for individuals or households to prefer red meat when buying meat was found to be statistically significant at the 5\% level. Consequently, as the level of education increases, the probability that consumers choose the market instead of those outside the market increases by 2.28 times (Table 4).

The amount of red meat being consumed is influential on the consumers' choice of place of purchase. The meat quantity variable is statistically significant at the level of $5 \%$ in the purchase place preference. The coefficient of the meat amount was negative. In this context, as the amount of red meat consumed decreases, it is 


\section{Red Meat Consumption Structure and Consumer Behavior in the Urban Area of Adana Province}

seen that the probability of people choosing the market instead of those other than the market increases by 0.98 times (Table 4 ).

The freshness of the meat is a very important factor in the consumer's choice to choose the market or not at the level of $1 \%$. As the freshness of the meat increases the probability of preferring the market increase by 1.35 .
The closeness of shopping is an important factor a $5 \%$ level for consumers to choose red meat buying places. As the closeness of the shopping increases, the probability of preferring the market to those other than the market is $\mathbf{1 . 5 6}$ higher.

Table 4. Binary logit model results

\begin{tabular}{lllllll}
\hline Variables & Coefficient & S.E & Wald & $d f$ & $\begin{array}{l}\text { Significance } \\
\text { level }(P)\end{array}$ & $\begin{array}{l}\text { Exp } \\
\text { (Coefficient) }\end{array}$ \\
\hline Education & 0.251 & 0.218 & 1.327 & 1 & 0.024 & 2.286 \\
Red meat quantity & -0.018 & 0.14 & 1.508 & 1 & 0.022 & 0.982 \\
Fresher & -1.029 & 0.253 & 16.549 & 1 & 0.000 & 1.358 \\
Being close & 0.495 & 0.178 & 7.690 & 1 & 0.006 & 1.563 \\
C (constant) & 2.004 & 1.020 & 13.859 & 1 & 0.000 & 7.422 \\
\multicolumn{1}{c}{ Loglikelihood: 300.477} & & Cox\&SnellR ${ }^{2}: 0.072$ & & NagelkerkeR $^{2}: 0.122$ \\
\hline
\end{tabular}

\section{Conclusion}

The purpose of the study was to determine the factors influencing the consumption of red meat in Adana. The annual amount of red meat intake per capita was estimated to be $22.02 \mathrm{~kg}$. The study found that customers chose to buy red meat from the butchers. Consumers favor boneless beef, no matter the income group by $70 \%$. When the customers buy red meat, they pay special attention to their family member's tastes, the cost, and the origin of the animal.

In the study, consumers' behaviors toward red meat were examined and the factors that affect change in red meat consumption were analyzed with help of the logit model. The increased level of education of the consumers increases the consumption of red meat as well. As aware people get about healthy nutrition, they consume more red meat. On the other hand, increased wealth contributes to the further consumption of red meat. And the increase in the number of individuals in the family reduces the intake of red meat. We may equate it with the high price of the meat. In addition, it was also found that consumers consume more red meat when the price of red meat decreases.

A balanced diet is necessary for a stable and quality community. For this purpose, training programs should be coordinated by government entities in charge and non-governmental organizations, to teach and encourage consumers to have a safe diet. Although it seems like a short-term solution to reduce import freedom and customs duties to prevent high meat prices in the market, it manifests itself as an application that harms the livestock industry. To support animal husbandry rural development is indeed needed. In this context some measure could be taken to improve livestock production;

- Animal farming, because the production quality is at the target level. Breeding work should be part of a state strategy. The Ministry of Agriculture, Industry Organizations and Universities should cooperate.

- Planning to eliminate income inequality between rural and urban by having more opportunities for education and jobs in rural areas.

- Preventing migration from rural to urban areas with subsidies, social project, infrastructure, investments

- The number of animals on the run has increased in recent years. These animals are not subject to any regulation which cause a substantial decrease in the number of animals and an increase in animal diseases. Food, Agriculture and Livestock Ministry No. 2015/04 Combating Animal Disease Control and Animal Movement Guideline has been released. This guideline should be applied rigorously. 


\section{Red Meat Consumption Structure and Consumer Behavior in the Urban Area of Adana Province}

- In order to prevent animal diseases, medical facilities should first be extended. Vaccination services need to be coordinated. Specifically, the distribution of disease areas should be calculated. These animals should be placed in isolation or they should be destroyed. The

\section{References}

Akbay, C., Boz, İ., (2005). Turkey's livestock sector: production, consumption and policies. Livestock Research for Rural Development, 17(9):1-14.

Akdemir, Ş, (1989). Structure of food consumption in the World and Turkey. Ç.Ü. Agriculture Faculty Journal, Number: 6, Adana.

Anonymous., (2015). Kırmızı et stratejisi. Hayvancilık Genel Müdürlüğü, 73p, Ankara.

Anonymous., (2016). Meat and seafood production consumption. https://ourworldindata.org/meat-andseafood-production consumption\#percapita-trends-in-meat-consumption 25/09/2019.

Armağan, G., Akbay, C., (2007). An econometric analysis of urban households' animal products consumption in Turkey. Applied Economics, pp.1-8.

Cankurt, M, Miran, B., Şahin, A., (2010). Sı ğır eti tercihlerini etkileyen faktörlerin belirlenmesi üzerine bir arastırma: İzmir ili örneği. Hayvansal Üretim, 51(2), 1622.

Ceylan, M.. (2006). Van ili kentsel ve kırsal alanda et ve ürünleri tüketim yapisı ve tüketicilerin satın alma eğilimleri. Yüksek Lisans Tezi. Yüzüncü Yıll Üniversitesi, Fen Bilimleri Enstitüsü, $71 \mathrm{~s}$.

Gogus., A.K., (1986). Meat technology. Ankara University Faculty of Agriculture Publications: 991, pp. 243, Ankara.

Gökçek, A.A., (1998). Edible oil consumption of families in the urban area of adana province and estimation of spending flexibility of oil. Ç.Ü Institute of Science, Agriculture Department of Economics, Master Thesis, Adana. expenses of these animals shall be paid in due time and in full.

- Increasing the support for fattening cattle, Purchase guarantee for living animals and red meat produced, in other words, a market must be found for producers.

Hanta, B., (1984). Animal food consumption structure in the urban area of adana province. Ç.Ü Institute of Science, Department of Agricultural Economics, Master's Thesis, Adana.

Hatırlı, S.A., Özturk, E., Aktaş, A.R. (2007). An analysis of demand of red meat, fish and chicken using full demand system approach. Journal of Suleyman Demirel University Institute of Social Sciences, 2007/2: 6.

Karl1, B., Bilgiç, A., (2007). Factors affecting meat and meat products consumption quantities in Şanllurfa province. Journal of Akdeniz University Agricultural Faculty, 20(1): 127-136.

Kızıloğlu, S., Kızıloğlu, R., (2013). Erzurum merkez ilçede et ve ithal et tüketme durumunu inceleyen bir araştırma. Igdır Uni. Fen Bilimleri Enst. Dergisi. 3(1), 6168.

Lorcu, F., Bolat, B.A., (2012). Edirne İlinde Kırmızı Et Tüketim Tercihlerinin İncelenmesi. Tekirda ğ Ziraat Fakultesi Dergisi, 9(1), 71-85.

Merve, A., (2017). Kırmızı ette fiyat oynaklığ1 ve tüketici davranışları. Gaziosmanpasa Üniversitesi, Fen Bilimleri Enstitüsü, Doktora Tezi, Tokat, 147s.

Mutlu, S., (2007). Gıda güvenirliği açısından tüketici davranışları (Adana kentsel kesimde kırmızı et tüketim örneği). Ç.Ü. Fen Bilimleri Enstitüsü, Tarım Ekonomisi Anabilim Dal1, Doktora Tezi, Adana.

Pazarlioglu, M.V., Miran, B., Ucdogruk, S., Abay, C., (2007). Using econometric modelling to predict demand for fluid and farm milk: a case study from Turkey. Food Quality and Preference, 18: 416424.

Sanchez, M., Sanjuan, A.I., Akl, G., 2001. The influence of experience in consumption 


\section{Red Meat Consumption Structure and Consumer Behavior in the Urban Area of Adana Province}

and personal attitudes on the purchase of lamb and beef. 71st EAAE Seminar, Zaragoza-Ispanya.

Stock Jh, Watson Mw., 2007. Introduction to econometrics. Pearson Addison Wesley, Boston.

TÜİK., (2018). http://www.tuik.gov.tr/ PreIstatistikTablo. do?istab_id=685 Erişim Tarihi: 08.07.2019

Upton, N., (2004). The role of livestock in economic development and poverty reduction. A Living from Livestock, FAO, $57 \mathrm{p}$.

Uzunoz, M., Akcay, Y., Aslan, C,. (2011). Factors affecting consumer preferences of food away from home in Tokat Province of Turkey. Bulgarian Journal of Agricultural Science, 17 (No 5) 2011, 597-605.

Yaylak, E., Taşkin, T., Koyubenbe, N., Konca, Y., (2010). A Study on determination of red meat consumption behaviors in Ödemiş, İzmir. Journal of Animal Production, 51(1): 21-30.

Yen, S.T., Lin, B.H., Davis, C.G., (2008). Consumer knowledge and meat consumption at home and away from home. Food Policy, 33: 631-639. 